Article

\title{
Regional Cooperation Ecosystem: Case of the Žilina Self-Government Region (Slovak Republic)
}

\author{
Jakub Soviar *, Martin Holubčík (iD) and Josef Vodák \\ Department of Management Theories, Faculty of Management Science and Informatics, University of Žilina, \\ Univerzitná 8215/1, 01026 Žilina, Slovakia; Martin.Holubcik@fri.uniza.sk (M.H.); Josef.Vodak@fri.uniza.sk (J.V.) \\ * Correspondence: Jakub.Soviar@fri.uniza.sk; Tel.: +421-41-513-4462
}

Received: 30 April 2018; Accepted: 25 June 2018; Published: 28 June 2018

check for updates

\begin{abstract}
The paper deals with the topic of the cooperation ecosystem in the Žilina higher self-government region (HSGR). The results are mainly from our research about cooperation in the region. According to the research results, the most developed areas of the cooperation are: the supplier-customer relationships, techniques and technology, education, legal service, marketing, transport, research and development. Research also finds more possible capacity for further cooperating connections. For example, the University of Žilina (UNIZA) and HSGR are natural cooperation centers and are both highly sought for as cooperation partners. Based on our findings we designed a model of the cooperation ecosystem, or cooperation platform in the Žilina self-government region. This platform should be formed by UNIZA and HSGR and other organizations for development of new cooperation projects in the region. Thanks to the dynamic and sustainable character of the platform it can easier react to changes on the market.
\end{abstract}

Keywords: cooperation management; partnership; cooperation; regional management; Žilina higher self-government region (HSGR); ZIP-Žilina innovation policy; cooperation research; regional cooperative platform; regional cooperation ecosystem

\section{Introduction}

The cooperation of the components within an organization is a matter of course. The cooperation of independent organizations is also the matter of course, today, as well. We can say that competitiveness is a goal of both. When we look closer at the interorganizational cooperation, we find out that if it is to be efficient, it must have partnerships relatively long and based on mutual trust. This can be demonstrated on the example of the supplier-customer relationships: KIA (and their production plant at Žilina), has created an efficient partnership with Siemens. Siemens does not only supply just-in-time, but also takes over all the responsibility that the specific part gets to the specific point of a production line at a specific time. This means that the employees of Siemens are directly in the production hall. They take care of their parts, from unloading through to the quality check-up, including into the production process. KIA saves costs on e.g., human resources, quality control, etc. since they pay a few times higher price to the company Siemens than to other suppliers. It is necessary to say that a key electronic part is concerned, and that Siemens bears, also, a higher risk and cost for a higher profit. Such cooperation is advantageous for both parties involved; it is based on mutual trust, it is contracted, and long-term-based. It helps both engaged parties achieve their strategic competitiveness. Many more examples and possibilities can be found within a similar definition.

Our research focuses on how these effects manifest on the higher regional level. Therefore, we analyzed mainly cooperation signs like supply and demand for cooperation by local companies, main partnerships, main areas of cooperation, and the most important cooperation centers. Based on our findings, we were able to describe the regional cooperative ecosystem, which can significantly 
influence the competitiveness of regional players. Three main initial hypotheses have been completed according to the research goals and theoretical analysis. These hypotheses helped us to better understand, describe, and research the degree of cooperation in the region. Therefore, the hypotheses can be understood as our main research bases.

Hypothesis 1. The elements in modern social and economic systems based on the principles of the market economy and economic competition - i.e., organizations and individuals - have natural tendencies to cooperate together and to create partnerships which provide them with more efficient operation, increase in added value and competitiveness, by which the competitiveness of the regional units they operate in increases.

Hypothesis 2. The elements of a social economical system in the selected region have created long-term partnerships, they are interested in the proper cooperation-to build and develop the cooperation.

Hypothesis 3. The active cooperation and partnership among the elements of the social economical system (regional entities) is based on management through the tools of the science on the management and the practical management.

\section{Materials and Methods}

In terms of possibilities for modern needs of the cooperation management, we have further analyzed the Žilina region-its cooperation potential. According to the results of the analyses, we will state the strategic recommendations of the efficient cooperation interconnections and their possibilities. To be able to understand the phenomenon of the cooperation management, it is necessary to study them in a scientific way. The detailed analysis of the higher self-government region (HSGR) has been done in such terms within the author's research work.

The aim of the research was to find out the main cooperation areas in the Žilina region, to provide relevant information for close interorganizational cooperation. It was necessary to design and conduct an intensive survey, because the information needed was not available. This makes the survey unique in both the regional and Slovak context.

The research object was cooperation supply and demand in the region, and main cooperation processes and areas.

Research methods: document analysis (analysis of secondary sources, analysis of scientific literature; used in theoretical analysis, and analysis of secondary sources about the region), empirical research (questionnaires; used for primary research surveying regional companies and organizations), comparative analysis, statistical analysis (qualitative and quantitative), historical method, common scientific methods: induction, deduction, synthesis, and abstraction.

We will present selected results from our research considering cooperation management. Our research started in the year 2008, and continued until 2015. Here, we want to present findings from the 2015 quantitate survey. The basic file was set to 1742 entities. A total of 1250 questionnaires were sent off. Of these, 492 entities had an inactive electronic address, and 176 questionnaires were returned back. Forty-two of these questionnaires were excluded due to the essential mistakes and bad filling in. One hundred and thirty-four respondents have been a representative sample of the survey. We updated these data and completed them with the following research:

- Research within CAF model (Common Assessment Framework) application at the UNIZA, where the authors studied perceiving and position of the UNIZA in the public of the region Žilina, as well as among the students of the UNIZA (2009-2010). Three hundred and twenty-eight respondents took part in the survey.

- A survey within the project of the cross-border cooperation of the Slovak Republic-Czech Republic called Innovations - a Road to Increasing of a Competition Ability and Development of Regions, where, inter alia, the interest of small and middle businesses in the cooperation with UNIZA and 
their participation in the existing cooperation was examined. The survey was made in 2010 on a sample of 314 small and middle businesses from the region Žilina.

\section{Theoretical Analysis}

The main theoretical backgrounds to the topic of cooperation are present in basic findings of psychology, sociology, anthropology, social psychology, and biology.

We consider biological and social predispositions of a man as a base for the efficient interpersonal cooperation. A man is a social being in his nature and a small social group, i.e., a tribe or a band, is a historical basis of the gregarious life of people. The efficient division of work has always been a basis to survive for human society. Different objectives may be achieved much more efficiently by the combination of the character features and abilities of individuals participating in a group, than by achieving them by individuals alone. This concerns the time, way, and quality of the achievement of the given objectives. The cooperation is based on the biologically given ability to plan, divide work, and submit to the authority. The authority represents a controlling element. The natural authority combines experience, abilities, and a significant personality in them. The ability to cooperate is natural, and enables people to combine their abilities at the achievement of the stated goals [1-8].

Modern society is so diversified and complex that the cooperation must be coordinated in the broadest sense. Efficient distribution of work is a basis of society development. Natural abilities have become the subject of scientific exploration and practical solutions. In such meaning, we can talk about the social psychological basis of cooperation $[2,8]$.

The effective cooperation of economic units may improve their competitiveness [9-19].

The success and survival of the market is conditioned by seriousness and politeness. The last two terms should be further explained, since they are used in many different connections and situations.

Austrian Nobel Prize Laureate Konrad Lorenz defined politeness as a regulatory system of society and an individual [3-5]. It contains several important elements: moral criteria, willingness to punish impolite/immoral behavior, and especially, the realization that the individuals may fail, but society must not. Robert Axelrod [20] explored cooperation by simulation models. Based on his models we can state following main conclusions:

- Cooperation leads to success on a long-term horizon (e.g., in a simulation, the final number of turns)

- A part of successful strategy of an individual, a group or organization's behavior is, besides cooperation, also a necessity of its control-reward and punishment (social control theory)

- Seriousness means reliability, honesty, respectability, and seriousness of intentions and conduct $[3-5,21]$

The cooperation is common planned work of more subjects (employees, companies, etc.) at the same work process or at similar work processes. The organized participation of a few entities at the production of a particular product (service) based on division of work [2,8,21-23].

Partnership means more intensive cooperation which is long-term, based on seriousness and politeness [24].

The above definitions of the terms result in the fact that the entities which cooperate efficiently are primarily serious and polite to each other. Such a relationship in a long-term horizon leads to trust. However, it should be pointed out here that such trust is focusing only on cooperating-partnership entities. Just on the market, the partnership cooperation may be created in order to improve competitive position of cooperating entities here (e.g., clusters etc.).

For the needs of integration of the above definition, it is proper to use the term cluster principle $[15,16,25]$. Such a principle consists particularly of cooperation of different economic entities with no disturbance of their potential competitive relationships. Building of the relations based on cooperation showing the following signs are concerned [11-14,17,26-28]: cooperation and partnership; seriousness; non-disturbance of mutual competitive relationships; focusing particularly on long-term time horizons/long-term cooperation. 
The cluster principle is of some philosophical basis here, in fact. That means that the essential basis is used from the cluster matter, which is then introduced to the relationships in the wider environment and connections.

\section{Results}

\subsection{Brief Characteristics of the Žilina Self-Government Region}

Žilina region covers an area of the northwest of Slovakia. It has a good geographic position on the border of three countries. It borders with the Czech Republic in the northwest. In the north and northeast, it borders with the Republic of Poland. In the east it borders with Prešov, in the south with Banská Bystrica, and in the west with the Trenčín region. The region has five basic regional units containing 11 districts; 19 municipalities of 314 have achieved the statute of a town. The district towns of the region are as follows: Žilina, Bytča, Čadca, Dolný Kubín, Kysucké Nové Mesto, Liptovský Mikuláš, Martin, Námestovo, Ružomberok, Turčianske Teplice, and Tvrdošín.

According to the last census in 2016, 690,434 inhabitants live in the Žilina region permanently, which is $13 \%$ within Slovakia, of which there are 351,317 women and 339,117 men. There are 346.6 thousand economically active people, of which 151.2 thousand are women and 195.4 thousand men. The share of economically active inhabitants in the region is $49.8 \%$. There are $20.4 \%$ people are in pre-productive age, $62.2 \%$ in productive age, and $17.0 \%$ people are in post-productive age in the region. The district Žilina is the most populated, district Turčianske Teplice is the least. About $51 \%$ of inhabitants live in the towns of the region; the biggest city is Žilina, and the smallest one is Rajecké Teplice.

Žilina region has a mountainous landscape. Agricultural land covers only a small part of it. The population is concentrated in valleys, especially in towns. The area of the Žilina region is the place with the highest density of protected territories in Slovakia (55.8\%). Wood is one of the most important raw materials, thanks to the high density of forests in the region ( $55.3 \%$ of the whole area of the Žilina region). A number of mineral springs and geothermal waters is to be found in the region. Žilina region has four territories that have been declared national parks. There are also four protected landscapes, 62 national natural reserves, 39 natural relics, and nine natural protected relics [29,30]:

- Area: $6809 \mathrm{~km}^{2}$

- Population: 690,434

- Population density $\mathrm{km}^{2}: 101.4$

- $\quad$ Largest towns: Žilina, Martin, Liptovský Mikuláš, Ružomberok, and Čadca.

\subsection{The Cooperation Potential of the Žilina Region}

Any form of cooperation which corresponds to a cluster principle relatively has a potential to produce added value. As a result of this, it is necessary to know the regional environment structure and areas of cooperation of the regional entities. The HSGR, as the whole Slovak Republic, has been experiencing economic growth. Investments are coming, new work positions are appearing, urban and traffic infrastructure is being built. The negatives of such processes include, especially, the slow rise of wages, lack of qualified and highly-qualified labor force, rising price of real estate, and increase in inflation.

Fundamental industrial branches $[29,30]$ :

- Electricity, gas, steam, hot water production

- Cellulose, paper, and paper product production

- Machine and mechanism production

- Electrical and optic equipment production

- Alimentary production

- Metal production 
Main Industrial Parks and direct foreign investments [29,30]:

- Neusiedler SCP a.s.- - leading manufacturer of wood-free graphic and office papers and boards in Slovakia and one of the leading manufacturers in Europe,

- KIA Motors Corporation,

- Schaeffler (former INA) (machinery),

- Volkswagen (automotive),

- Tento (chemical, wood processing and paper industry).

The following data are thus based on the data from the above surveys. The author has tried to map the region Žilina in terms of the cooperation potential-the demand for the cooperation and the created cooperation connections by them. According to the survey, most of the regional entities (74.8\%) have close, almost partner relationships with another organization. This is natural for the market economy. A lot of opinions from experts on the topic of clusters consider the Slovak Republic as still culturally oriented to non-cooperation, individualism, a centralistic approach, and patronage. Such problems are referred to as cultural residuals from the era of the centrally managed economy (1948-1989). The abovementioned cultural aspects of the economic and political system are considered as transitive ones, i.e., situated in the transition to the full-valued democracy (free market, free business, political democracy, etc.). The survey has rebutted the factors related to non-cooperation. The survey has proven that the regional entitles cooperate closely with each other-they form long-term partnerships, which mean the advantages or added value to participating parties. Regarding distrust, it is a natural human character feature, and it is, again, natural that trust is based on the positivity of the experience.

The survey has identified areas of the cooperation of the regional entities in the Žilina region, as well as average satisfaction of the respondents with the cooperation in such areas. A scale from 1 to 10 was used to evaluate, where 1 is the smallest and 10 is the biggest satisfaction. For better limpidity, the general areas have been chosen upon a study of various data about the region (statistical, economic, development, etc.), as well as the results of the project Innovation Policy of Žilina-ZIP (www.zip.uniza.sk) in which the author has also participated. The following graph (Figure 1) shows the areas of the cooperation of the regional entities in the region Žilina. The following table (Table 1) shows the satisfaction in particular areas.

Table 1. The average satisfaction of companies in the areas of cooperation (scale 1-10).

\begin{tabular}{cc}
\hline Areas of Cooperation & Average Satisfaction \\
\hline Logistics & 7.5 \\
Product and service consumer & 7.3 \\
Other & 7.3 \\
Product and service supplier & 7.2 \\
Technical cooperation & 7.1 \\
Technical consulting & 7 \\
Financial and banking services & 7 \\
Legal services and consulting & 6.7 \\
Research and development & 6.6 \\
Ecology & 6.6 \\
Education & 6.5 \\
Advertising, promotion & 6.5 \\
European Union funds and projects & 6.3 \\
Transport & 6 \\
Financial consulting & 5.8 \\
Media & 5.6 \\
Marketing & 5.3 \\
Management & 5.2 \\
Investments & 4.8 \\
\hline
\end{tabular}




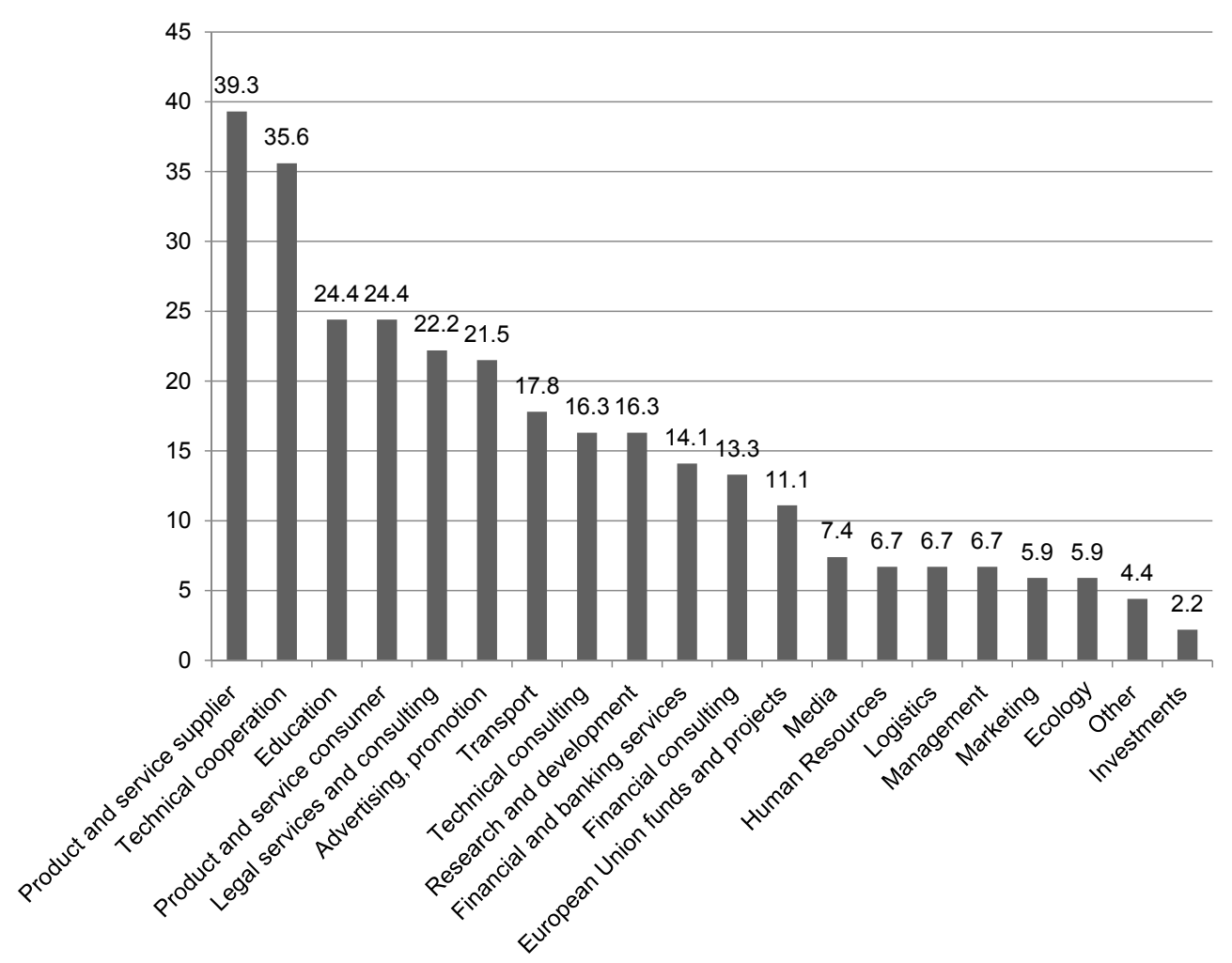

Figure 1. The areas of existing partnership cooperation in the region of Žilina in \%.

The results prove that the cooperation in the Žilina region has been developed. The most developed areas have been formed within the supplier-customer relationships. The regional entities try to build and develop them with their suppliers. The cooperation is mostly long-term, often based on personal contact. The cooperation is also based here on the recommendations, good will, and personal experience. The regional entities try to reassess the inconvenient cooperation and to look for serious suppliers. The cooperation within technologies corresponds to the industrial character of the region, as well as to the high importance of technologies. The continuous education in turbulent space of today is a must for the commercial sector. Keeping the key customers-purchasers-is the base of a successful business as well. The intensive cooperation and communication are a condition here. The legal services are necessary, and a lot of businessmen cooperate with the established law offices or specialists.

Let us have a look at what kind of organizations the economic entities of the region mostly cooperate with. The following figure (Figure 2 ) states the organizations which are mostly cooperated with in the region in percentage.

Consulting and foreign organizations represent suppliers and customers here. This area is obviously the most developed one, because it relates directly to the operating of a transformation chain in the broadest sense. The high rate of cooperation with non-profit organizations means that the entities have formed the partnerships with the non-profit sector in the areas according to their needs and interests. The high rate of cooperation with universities also proves their unique position-they are frequently searched partners in the cooperation in the different areas (education, building and development of labor force, science, research, etc.). There is an important finding that $61.2 \%$ of the respondents are interested in the intensive cooperation partnership within 1 year. That means that the region still has a real capacity for the development of the cooperation. Such capacity has been measured as a demand for the cooperation. The following graph (Figure 3) states the demand for cooperation in the frame areas in percent. 


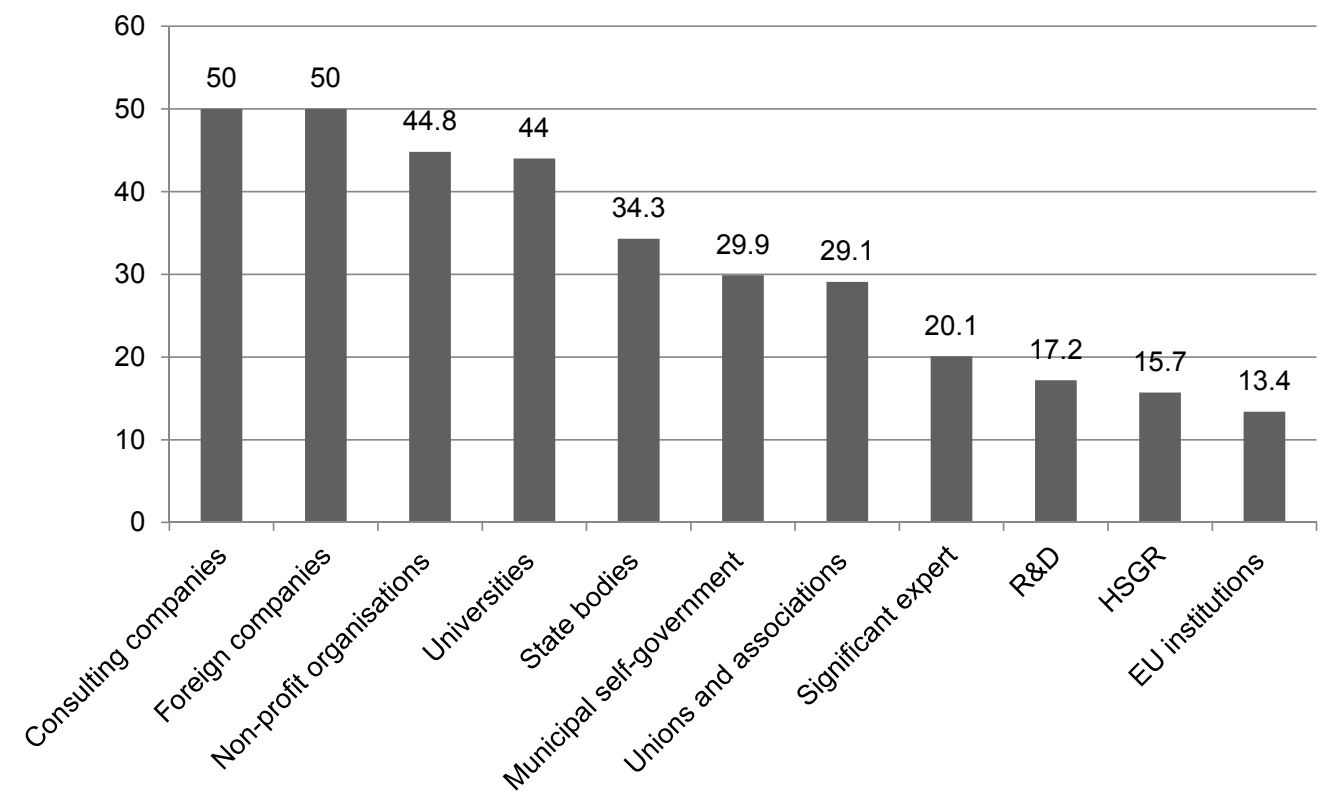

Figure 2. Who are cooperated with in the Žilina region (in \%).

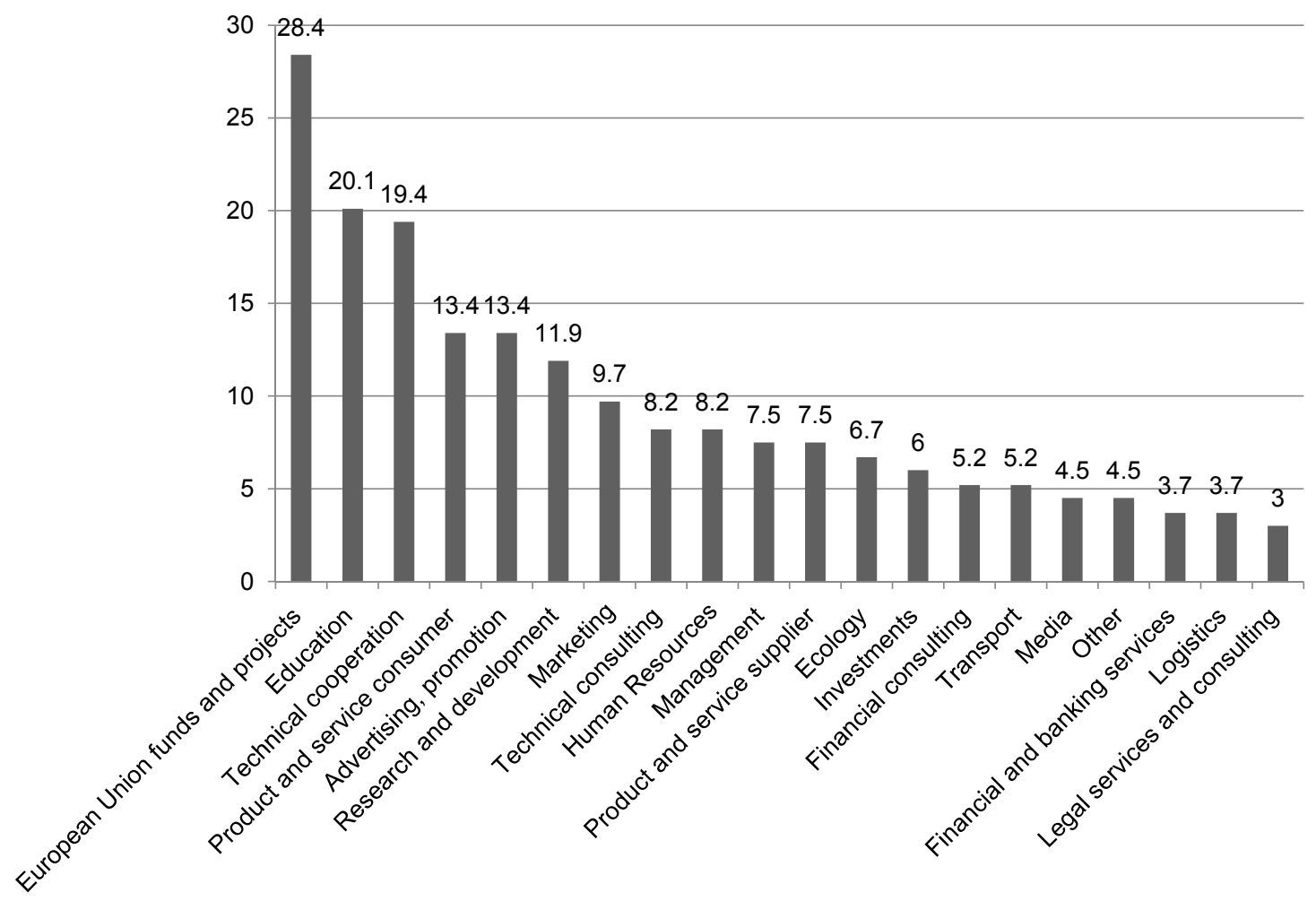

Figure 3. The areas of the demand for the cooperation in the Žilina region (in \%).

The high interest in the funds and projects of the European Union has been motivated by the real availability to obtain such subventions, as well as by the persisting barriers in this area (particularly the lack of information, complexity of the process, complicated administration, etc.). The demand for education has been caused particularly by the frequent changes in the legislation, as well as by the innovations in the area of technologies and other processes. It is thus necessary to educate the labor force depending on the current needs. The area of technologies is really a key one in the broadest 
sense. Here, it relates to production companies and their technological needs, as well as PC operation and work with specialized software. The categories with the low rate of interest have already been covered in a cooperation way. That can mean that there is simply no interest, however, on the other hand, it shows that there are long-term partnerships in these areas.

In the following figure (Figure 4) there are the main organizations in the region, which have been identified as natural partners for the cooperation in different areas.

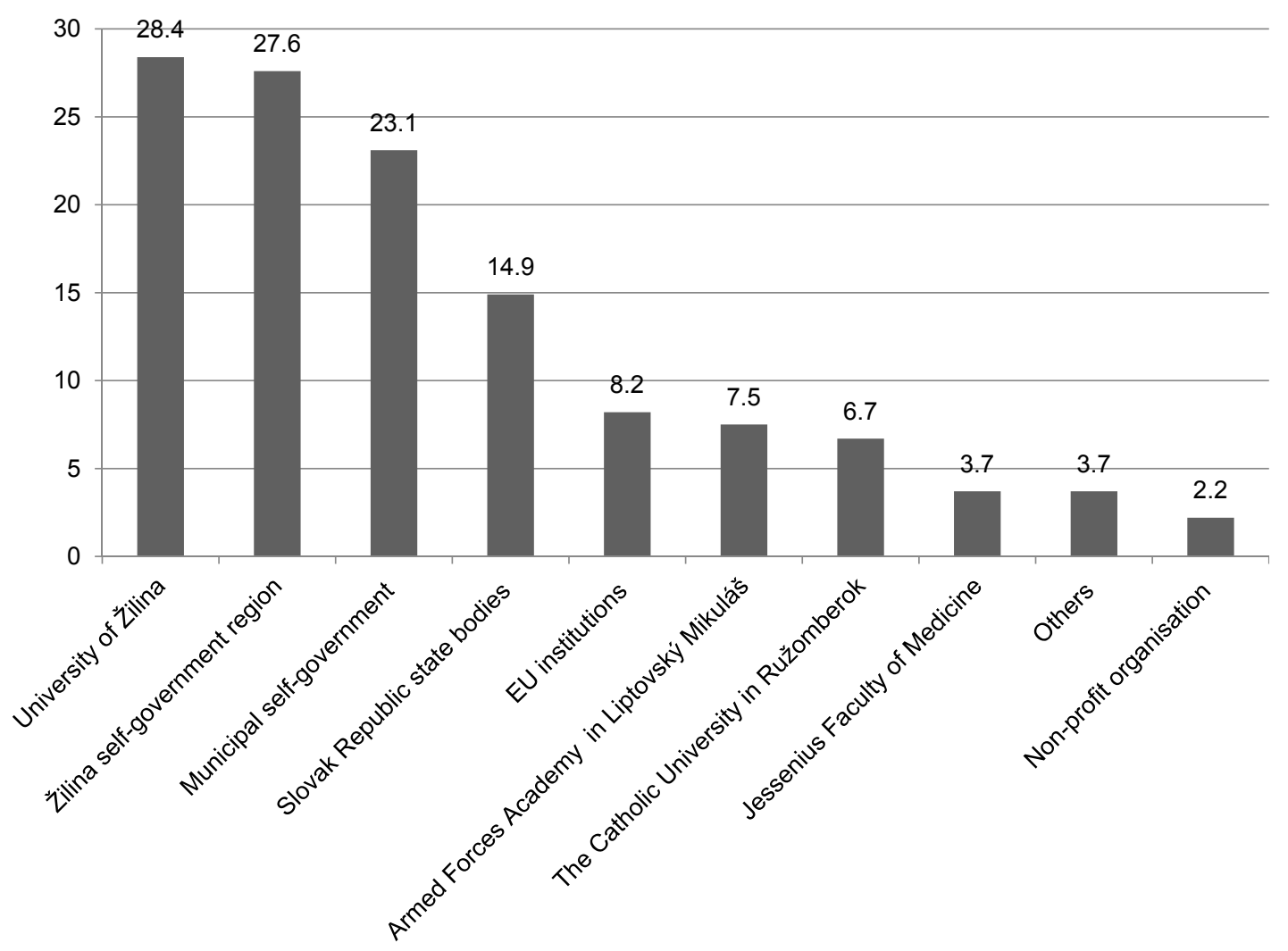

Figure 4. The demand for the cooperation-organizations (data in \%).

The results have shown two interesting effects. The first one is that some organizations show the high demand, despite the high amount of already-existing cooperations. UNIZA, which is the biggest and the oldest university in the region, is an example. Its position is unique-people trust it a lot and the cooperation with it has already become traditional. This cooperation has even been developed (approximately $44 \%$ of the respondents cooperate with universities). Despite that, UNIZA is in an extraordinary demand for cooperation. The other effect is a low number of really existing cooperation interconnections, but the high demand for the particularly significant demand for cooperation with HSGR (the higher self-government region). This cooperation has been developed only little ( $15.7 \%$ of the respondents cooperate with HSGR). That means that HSGR is perceived as a natural cooperation partner by people-however, this factor has not been developed (proven by the high demand).

Considering the significant position of the UNIZA in the region, we want to provide data from the survey within CAF model application. As we can see there in the table (Table 2), the perceived position of the UNIZA is very strong among respondents.

From the survey Road to Increasing of a Competition Ability and Development of Regions, we focus on selected results considering partnership and cooperation (Table 3). Respondents, regional business organizations, claim a relatively high level of satisfaction with suppliers' and customers' seriousness. We can observe the same situation, high level of satisfaction, considering the partnership-based relations with suppliers and customers. 
Table 2. The position of UNIZA in Žilina region.

\begin{tabular}{|c|c|c|c|c|c|}
\hline & $\begin{array}{l}\text { I Agree without } \\
\text { Any Conditions }\end{array}$ & $\begin{array}{l}\text { I Agree with Some } \\
\text { Conditions }\end{array}$ & $\begin{array}{l}\text { I Am More Inclined to } \\
\text { Disagree than Agree z }\end{array}$ & $\begin{array}{l}\text { I Absolutely } \\
\text { Disagree }\end{array}$ & I Do Not Know \\
\hline $\begin{array}{l}\text { University of Žilina has a positive influence on life } \\
\text { in the region }\end{array}$ & $50.91 \%$ & $33.54 \%$ & $4.88 \%$ & $3.05 \%$ & $7.62 \%$ \\
\hline $\begin{array}{l}\text { University of Žilina has a positive influence on } \\
\text { local and regional economy }\end{array}$ & $49.09 \%$ & $32.62 \%$ & $4.27 \%$ & $3.05 \%$ & $10.98 \%$ \\
\hline $\begin{array}{c}\text { University of Žilina has a responsible approach to } \\
\text { solving problems of the town and region }\end{array}$ & $15.55 \%$ & $32.93 \%$ & $1159 \%$ & $3.96 \%$ & $35.98 \%$ \\
\hline $\begin{array}{c}\text { University of Žilina is one of the most successful } \\
\text { universities in SR }\end{array}$ & $27.44 \%$ & $35.98 \%$ & $15,55 \%$ & $10.37 \%$ & $10.67 \%$ \\
\hline $\begin{array}{l}\text { Conduct of the University of Žilina is open, ethical } \\
\text { and transparent }\end{array}$ & $23.17 \%$ & $39.02 \%$ & $10.06 \%$ & $5.79 \%$ & $21.95 \%$ \\
\hline $\begin{array}{l}\text { University of Žilina is socially and } \\
\text { environmentally responsible }\end{array}$ & $26.52 \%$ & $37.80 \%$ & $7.93 \%$ & $3.35 \%$ & $24.39 \%$ \\
\hline $\begin{array}{l}\text { I registered only positive news about the } \\
\text { University of Žilina in the news (TV, radio, press) }\end{array}$ & $24.09 \%$ & $35.37 \%$ & $19.21 \%$ & $4.57 \%$ & $16.77 \%$ \\
\hline
\end{tabular}

Table 3. Satisfaction with certain facts in Žilina region.

\begin{tabular}{ccccccc}
\hline & Excellent & Very Good & Good & Satisfactory & Unsatisfactory & Was Not Stated \\
\hline Credibility of suppliers & $12.14 \%$ & $46.01 \%$ & $28.43 \%$ & $7.35 \%$ & $1.92 \%$ & $4.15 \%$ \\
Credibility of consumers & $9.90 \%$ & $34.19 \%$ & $37.38 \%$ & $12.78 \%$ & $2.24 \%$ & $3.51 \%$ \\
Partnerships with suppliers & $21.41 \%$ & $50.16 \%$ & $19.81 \%$ & $3.83 \%$ & $0.32 \%$ & $4.47 \%$ \\
Partnerships with consumers & $15.34 \%$ & $48.88 \%$ & $25.56 \%$ & $7.03 \%$ & $0.32 \%$ & $2.88 \%$ \\
\hline
\end{tabular}




\subsection{Research Results Interpretation}

The following part states the hypotheses regarding cooperation in the HSGR. The hypotheses have been construed regarding the wider connections and results of the survey. We consider the construction and use of the hypothesis, mainly form the point of view of descriptive statistics. We present here what we have learned from the descriptive statistics.

It is possible to verify Hypothesis 1 through the knowledge on clusters, on advantages of the cluster principle, and on their influence on the rising competitiveness. From the specialized literature, it is necessary to mention M. Porter at this point: The Competitive Advantage and Clusters and the New Economics of the Competition, and the work of the authors Solvell, Goran, Ketels: The Cluster Initiative Greenbook, as well as other relevant knowledge on efficient intercorporation cooperation. Hypothesis 1 has been confirmed also by general knowledge from psychology, sociology, anthropology, and biology, which talk about a man as a social animal, and on cooperation as a basis for survival of mankind and groups. This fact applied both in older stages of human society, as well as in today's modern society. A man can develop and realize, only through the society, to full value. The cooperation is based on the biologically given ability to plan, divide work, and submit to authority-it is the basis for modern management at the same time. The ability to cooperate is natural, and enables people to combine their abilities at achieving the stated goals. Organizations can cooperate too, and their combined effort can increase their competitiveness. The successful cooperation of the organizations creates some added value, and thus, it affects its surrounding (a region), e.g., it creates new work positions, provides their employees with higher wages, the gained funds are invested, etc. Hypothesis 1 may be falsified through different development trends in the environment of free market. The following statements are particularly concerned:

- Competition as a natural matter of market mechanism inhibits the organizations from the cooperation and forces them to focus more on the efficient cooperation of their own employees.

- Patronage and bribery, which are natural matters of the human society, create a specific type of cooperation based on family relationships, on the relationships of a patron-client, on the relationships of reciprocity of the services ("something for something", "I will help you and you will help me"), on providing of financial and other advantages for free services, or for a better position, etc. Such cooperation creates added value, not only for the parties concerned. It may even affect, positively, towards keeping the integrity of the culture and society. Patronage and bribery may replace the missing formal control systems in more efficient informal ways.

- The cooperation may generate added value, however, this one may be utilized in a way which does not affect a wider surrounding, but only the main actors or owners of the concerned entities. E.g. the potential profit may be divided only among the owners, etc.

Hypothesis 2 may be verified through the data and findings from the research where it has been proven that $76 \%$ of the respondents have a long-term partnership created with another organization; the biggest share in the areas of the cooperation in the Žilina region consists of the supplier-customer relationships, up to $13 \% .62 \%$ of the respondents are interested in joining an intensive cooperation partnership for one year. The findings and results of the project Žilina Innovation Policy (ZIP) in the document Strategy Framework of the Žilina Region for the Area of Innovative Development form a significant source for the confirmation of the Hypothesis 2. Hypothesis 2 may be falsified through the following statements:

- The above research has been focused on a specific area of the knowledge of the regional environment, particularly, the area of cooperation. Further research, further data and findings could make this topic more specific, and change the interpretation of the found facts.

- The human behavior is reactive, which means that people tend to change their behavior if they know they are the subject of a research. The reactivity could, thus, influence the results in terms of their relevancy. 
Human behavior changes in time and space, that also means that the results of the research and other current sources of the data will be out of date, incurrent, and irrelevant after some time. These sources and results are also limited spatially for the Slovak Republic and the Žilina region, and their applicability in other conditions has been limited.

It is possible to verify Hypothesis 3 through the theoretical knowledge on clusters, or the cooperation and facts regarding the positive effect of a cluster principle on rising competitiveness. Next, it is also necessary to state the practical experience from the Czech Republic regarding the support to establish the clusters by the public agency Czechinvest [31]. The activity of this agency has led to the establishment of many currently functional clusters in the Czech Republic. It is again necessary to mention also the activities within the project ZIP where, besides others, also the cluster potential of the Žilina region has been mapped. This activity influenced establishing of the cluster initiatives in the Žilina region directly. The practical and theoretical tools of management- the management science-have special importance here. These may be used for the efficient management and administration in virtually all formal social organizations today. The efficient management as a science and practice is one of the important conditions of the successful existence of an entity on the market. The management tools are utilizable for the building of the cooperative interconnections. They are an essential prerequisite for arising or creating of the cooperation. Hypothesis 3 may be falsified through the following statements:

- The competitiveness achieved through the cooperation of different entities is unsure, and can lead to withdrawal of important sources, which may have even critical consequences for the entities concerned.

- The support of creation of the cooperation and clusters deforms natural competitive environment, since it makes it advantageous to only particular entities. The interest in cooperation may also be only an excuse to obtain the subventions or other aid.

- The application of the management of support of the interconnections and the cooperation building process disturbs a natural state of the market where the entities look for and build their cooperation themselves.

We can interpret the initial hypothesis thorough the set of partial hypotheses and their connections to the survey results. With the use of simple descriptive statistics, we claimed all of them as confirmed.

The commercial organizations tend to build partnership relations naturally, particularly with their suppliers, customers, or through closer connection with research and development.

- A total of $76 \%$ of the respondents have created a long partnership, of which $13 \%$ have created the partnership relations within the area of the product and service suppliers; $8 \%$ within the area of the product and service customers; and 5\%within the area of research and development.

There is an insufficient cooperation in the region between the commercial sphere and the public administration;

- whereby $34 \%$ of the respondents cooperate with the public sphere, and $66 \%$ do not.

There is an insufficient cooperation in the region between the commercial and self-government sphere.

- In the case of HSGR, $16 \%$ of the respondents cooperate with HSGR, $84 \%$ do not. In the case of the municipal self-government unit, the hypothesis has been confirmed only partially, since $31 \%$ of the respondents cooperate and $69 \%$ do not.

There is an insufficient cooperation in the region between commercial sphere and universities.

- About $44 \%$ of the respondents cooperate with universities, while $56 \%$ do not. 
There are a lot of areas of the cooperation where there is unused potential in terms of the increasing of efficiency and competitiveness-the regional entities have mostly unused capacity for the possible cooperation, as well as interest in extending of the cooperation.

- A total of $62 \%$ of the respondents want to start to cooperate with another entity within one year in different areas. From the number of the respondents which are interested in the cooperation, $62 \%$ showed interest in starting such cooperation with the UNIZA (22\%), with HSGR (22\%), with the municipal self-government unit (18\%), and with the public administration (12\%).

The possibilities of a cluster principle have been applied only minimally and the knowledge on them is small.

- Around $37 \%$ of the respondents have at least basic knowledge on clusters, $63 \%$ do not.

\section{Discussion and Conclusions}

The University of Žilina and Žilina higher self-government region are perceived as natural partners for cooperation projects in the region. These two entities (UNIZA and HSGR) should thus create a platform where it will be possible to make and develop cooperative partnerships (Figure 5). This regional cooperative platform (or cooperation ecosystem) should have, based on the found facts, also other levels, such as dynamic character, which would enable it to react to a current situation. The second level should consist of other regional universities and self-governments of district towns. The third level should be a dynamic one-that means different organizations could join it ad hoc. It should mostly be the following: the organizations intended to support the business with the national scope; out-of-region universities; secondary schools (regional and out-of-regional ones); the organizations focused on the regional development and cross-border cooperation; labor offices and personnel agencies (regional and out-of-region ones); the organizations dealing with research and development; the organizations focused on the transfer of the technologies and support of the innovations.

Such a dynamic cooperative platform (Figure 5) should then satisfy an identified regional demand for the cooperation in the following framework areas: European Union funds and projects; technical cooperation; education; advertising and promotion; product and service customer; research and development; lack of the required labor force. The offer (supply) responding to the above demand should be concentrated into the following framework areas: the facilitation of clusters; education, technologies, database of the regional entities-the area of their activity and possibilities of cooperation; cooperative projects with research and development; support of searching the proper labor force for regional entities, subventions, aid, support-the utilization of different donation mechanisms; marketing support of the regional subjects engaged in the cooperative projects.

What are the main processes which should run in the drafted regional cooperation platform? According to the above, the following should be considered: the building and developing of the interconnections with universities and self-governments; wide internationalization; education; collecting and evaluation of the information; providing the information; facilitation of cooperation and partnerships, marketing and PR.

The above sketch of the regional cooperation platform (cooperation ecosystem) has been based on the principles of efficiency and the building of the innovative environment. It is just the cooperation which is one of the most important elements of the innovation potential. This platform is not only an idea concept. Its particular parts or ideas are virtually realized. The abovementioned project ZIP can serve as an example, where it is just an intensive cooperation between the UNIZA and HSGR which started the innovation and cluster activities in the region. Based on this cooperation the building goes on, it is successfully developing. There are many examples of the real building of a "cooperation platform". Let us mention only that UNIZA is a demanded partner for the cooperation in the area of technologies or R\&D by important companies such as Siemens, KIA, WV, Scheidt \& Bachmann, and others. The above cooperation has been based on the positive experience, and it is developed 
permanently in favor of all parties concerned. It can be said that they meet the ideas of a cooperation management (efficient partnership based on the positive experience).

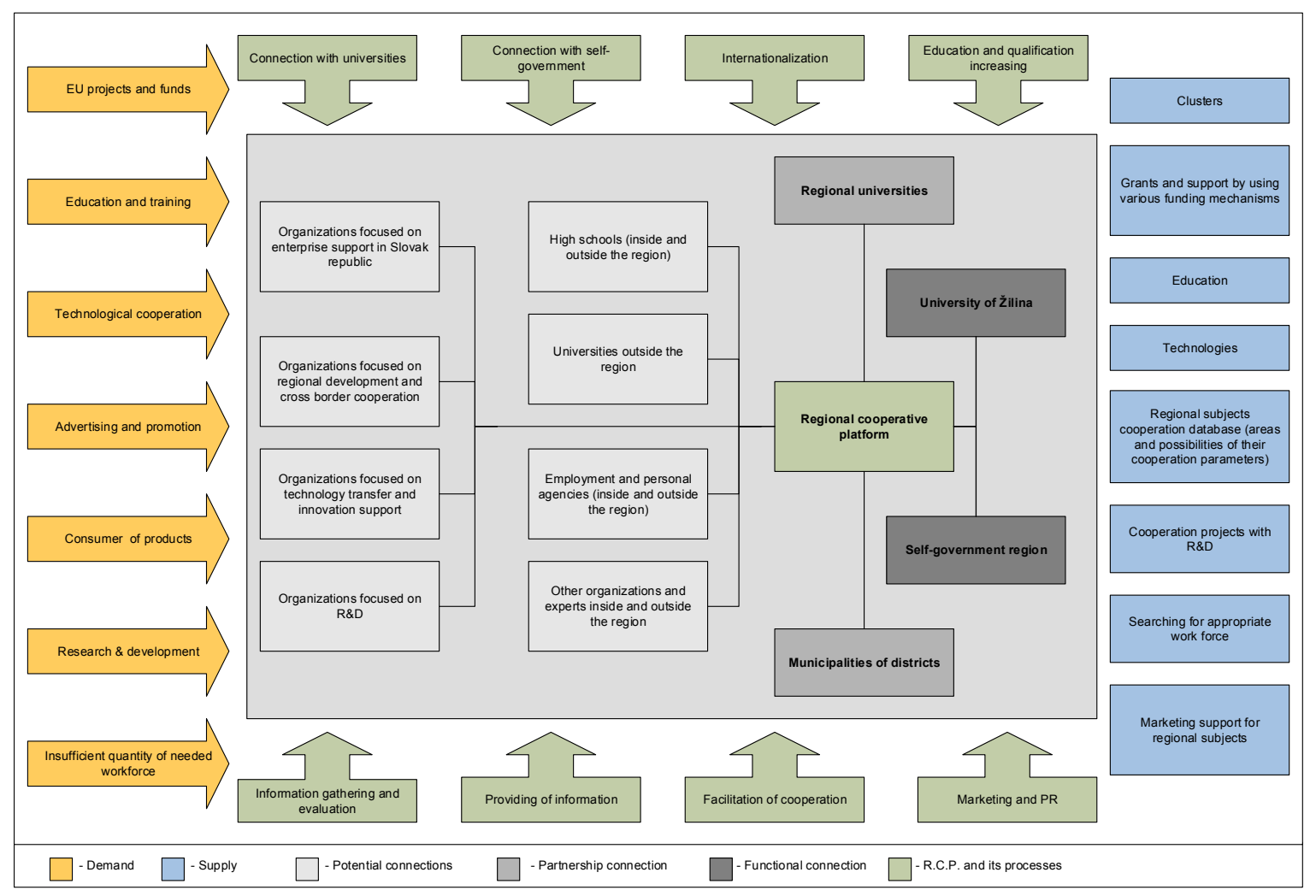

Figure 5. Žilina self-government region cooperative platform—cooperation ecosystem.

The above dates are also relevant for use in the regional management, particularly in the strategic planning of the HSGR. It should be said here that this has also been in progress. The data and conclusions of the ZIP project in the document Strategy Framework of the Žilina region for the area of the innovation development (Žilina self-government region's regional innovation strategy 2006 and regional research and innovation strategy 2014+), which serves as a base of the strategy policy in this direction. Other possible utilization possibilities are for the companies and organizations operating in the region, which are interested in the development or building of their cooperation relationships, and also for the organizations which want to cooperate with the regional entities or enter the regional market.

From the theoretical point of view, social sciences and biology say that social-economical systems have natural tendencies to create complex cooperative relationships based on positive experiences and positive reputation. Žilina region is one of these systems, and our research verified the natural tendencies to cooperate. These systems have a tendency to support the competitiveness of the participants. They also create positive externalities. Both situations were captured during our research. Theory states that serious partnerships are important for building long-term stable social systems. This was also verified by our research. Research also verified that using the cluster principles has a positive effect on building and growing of regional competitiveness. Therefore, our research is consistent with theory in the most crucial areas. The results of our research benefit the theory by providing proof of importance of cooperative strategy for regional growth and competitiveness. Theory sees cooperative strategy in business as one of the options. In the regional context, we were surprised by the significance of the cooperation quality for the progress of the whole system. Right here is where we see the contribution of our research to the theoretical knowledge. Briefly, it can be summarized like this: effective cooperative ecosystem and cooperation management are significant for the positive regional 
growth by strengthening the competitiveness of the region, but also its individual regional players. Ins conclusion: cooperation between economical entities in the Žilina region has been developed. However, it still has not achieved full capacity and identifiable demand. In terms of a brief summary, the following may be stated:

- The partnership cooperations exist, and they are efficient $(74.8 \%)$

- The most developed areas of the cooperation are as follows: the supplier-customer relations, techniques and technology, education, legal service, marketing, transport, research and development (R\&D).

- There is the capacity there for the further cooperating connections $(61.2 \%)$.

- Demand for the cooperation: European Union funds, education, techniques and technology, new customers, marketing, research and development.

- $\quad$ The UNIZA and HSGR are natural cooperation centers/partners.

In course of our research, we defined the condition of the regional cooperative system. From our point of view, it can be defined as an ecosystem, or a dynamic connection of important regional players with a common goal to create and improve regional competitiveness. We created an ideal image of this ecosystem from the strategic regional management point of view, which means that we considered the most important aspects of supply and demand and all the important cooperation connections.

Author Contributions: All authors participated in the research and shared joint responsibility for this work. J.S. is the main author of this research. J.V. and M.H. contributed equally, mainly to the discussion and research results presentation. J.S. provided the data collection and visualization. M.H. and J.S. drafted the manuscript. J.V. provided critical review of the text and improved methodology and overall presentation. All authors read and approved the final version of the manuscript.

Acknowledgments: This paper was partially supported by the Slovak republic scientific grants "VEGA $1 / 0617 / 16$ " and "APVV-15-0511". We would like to thank the two anonymous reviewers for their beneficial remarks and suggestions which help us improve the presentation of our research.

Conflicts of Interest: The authors declare no conflict of interest.

\section{References}

1. Giddens, A. Sociology, 6th ed.; Polity Press: Cambridge, UK, 2009; ISBN 978-0-7456-4358-8.

2. Hewstone, M.; Schut, H.; Wit, J.; Van Den Bos, K.; Stroebe, M. The Scope of Social Psychology: Theory and Applications, 1st ed.; Psychology Press: East Sussex, UK, 2007; ISBN 978-1841696454.

3. Lorenz, K. The Foundations of Ethology: The Principal Ideas and Discoveries in Animal Behavior, 1st ed.; Simon \& Schuster: New York, NY, USA, 1982; ISBN 978-0671445737.

4. Lorenz, K. Der Abbau des Menschlichen; R. Piper: München, Germany, 1983; ISBN 978-3492028332.

5. Lorenz, K. Die acht Totsünden der zivilisierten Menschheit; Piper Verlag: Zürich, Switzerland, 1983; ISBN 978-3492200509.

6. Gupta, C. The co-operative model as a 'living experiment in democracy'. J. Co-op. Organ. Manag. 2014, 2, 98-107. [CrossRef]

7. Qiu, H.; Bures, R.; Shehan, C.L. The inconsistent mediating effects of psychosocial work characteristics on the education-health relationship. Soc. Sci. Med. 2012, 75, 1539-1546. [CrossRef] [PubMed]

8. Hewstone, M.; Stroebe, W.; Jonas, K. Introduction to Social Psychology: A European Perspective; Blackwell Publishing: Oxford, UK, 2012; ISBN 978-1405124003.

9. Ahmedova, S. Factors for Increasing the Competitiveness of Small and Medium-Sized Enterprises (SMEs) in Bulgaria. Procedia Soc. Behav. Sci. 2015, 195, 1104-1112. [CrossRef]

10. Dosi, G.; Grazzi, M.; Moschella, D. Technology and costs in international competitiveness: From countries and sectors to firms. Res. Policy 2015, 44, 1795-1814. [CrossRef]

11. Gumilar, V.; Zarnić, R.; Selih, J. Increasing Competitiveness of the Construction Sector by Adopting Innovative Clustering. Inzinerine Ekon. Eng. Econ. 2011, 22, 41-49. [CrossRef]

12. Lydeka, Z.; Adomavičius, B. Cooperation among the Competitors in International Cargo Transportation Sector: Key Factors to Success. Eng. Econ. 2007, 51, 80-90. 
13. Malakauskaite, A.; Navickas, V. Relation between the Level of Clusterization and Tourism Sector Competitiveness. Inzinerine Ekon. Eng. Econ. 2010, 66, 60-67.

14. Malakauskaite, A.; Navickas, V. Contribution of Clusters to the Competitiveness of Companies: Revelation and Evaluation. Inzinerine Ekon. Eng. Econ. 2011, 22, 50-57. [CrossRef]

15. Porter, M.E. Clusters and the New Economics of Competition. Harward Bus. Rev. 1998, 76, 77-90.

16. Porter, M.E. On Competition; Harvard Business School Publishing: Boston, MA, USA, 1998.

17. Ramanauskienè, J.; Ramanauskas, J. Economic Management Aspects of Cooperatives. Eng. Econ. 2006, $49,15-21$.

18. Tödtling, F.; Maier, G. Regional- und Stadtökonomik I: Standorttheorie und Raumstruktur (Springers Kurzlehrbücher der Wirtschaftswissenschaften), 3. aktualisierte Aufl. ed.; Springer: Berlin, Germany, 2001.

19. Tödtling, F.; Maier, G. Regional- und Stadtökonomik II: Regionalentwicklung und Regionalpolitik (Springers Kurzlehrbücher der Wirtschaftswissenschaften), 2. erw. Aufl. ed.; Springer: Berlin, Germany, 2002.

20. Axelrod, R. The Evolution of Cooperation; Basic Books: New York, NY, USA, 1984; ISBN 978-0465005642.

21. Ivanová-Šalingová, M.; Maníková, Z. Slovnik Cudzích Slov; Slovenské Pedagogické Nakladatel'stvo: Bratislava, Slovakia, 1979; ISBN 80-08-00006-6.

22. Ferrin, D.L.; Bligh, M.C.; Kohles, J.C. It takes two to tango: An interdependence analysis of the spiraling of perceived trustworthiness and cooperation in interpersonal and intergroup relationships. Organ. Behav. Hum. Decis. Process. 2008, 107, 161-178. [CrossRef]

23. Robbins, S.P.; Coulter, M. Management, 11th ed.; Prentice Hall: Upper Saddle River, NJ, USA, 2012; ISBN 978-0-13-216384-2.

24. Jagosh, J.; Bush, P.L.; Salsberg, J. A realist evaluation of community-based participatory research: Partnership synergy, trust building and related ripple effects. BMC Public Health 2015, 15, 725. [CrossRef] [PubMed]

25. Zhu, Y. Conception Definition of Industrial Clusters. In Analysis of Industrial Clusters in China; CRC Press: Boca Raton, FL, USA, 2009; ISBN 9781420089202.

26. Rodriguez-Melo, A.; Mansouri, S.A. Stakeholder Engagement: Defining Strategic Advantage for Sustainable Construction. Bus. Strategy Environ. 2011, 20, 539-552. [CrossRef]

27. Skokan, K. Konkurenceschopnost, Inovace a Klastry v Regionálním Rozvoji; Repronis: Ostrava, Czech Republic, 2004; ISBN 80-7329-059-6.

28. Solvell, O.; Goran, L.; Ketels, C. The Cluster Initiative Greenbook; Brommatryck AB: Stockholm, Switzerland, 2003; ISBN 91-97478318.

29. Dado, M. Rámcová stratégia žilinského regiónu pre oblast' inovačného rozvoja. In Regional Innovation Strategy_Strategic Document of the Žilina Self-Government Region; University of Žilina: Žilina, Slovakia, 2006.

30. Dado, M. Regionálna výskumná a inovačná stratégia Žilinského kraja 2014+. In Regional Research and Innovation Strategy—Strategic Document of the Žilina Self-Government Region; VTP Žilina: Žilina, Slovakia, 2015.

31. Průvodce Klastrem, Czechinvest. Available online: http://www.czechinvest.org/data/files/pruvodceklastrem-63.pdf (accessed on 24 November 2017).

(C) 2018 by the authors. Licensee MDPI, Basel, Switzerland. This article is an open access article distributed under the terms and conditions of the Creative Commons Attribution (CC BY) license (http:/ / creativecommons.org/licenses/by/4.0/). 